Volume. 5 Number. 1

Period: January - June 2021; page 26-30

p-ISSN : 2580-1112; e-ISSN : 2655-6669

Copyrighr@2020

The author owns the copyright of this article

journal homepage: https://ejournal.akperfatmawati.ac.id

DOI : 10.46749/jiko.v5i1.58
Jurnal Ilmiah Keperawatan Orthopedi

(JIKO)

Article history:

Received: February 23, 2021

Revised: February 28, 2021

Accepted: March 03, 2021

\title{
Maintaining The Status of Hydration on Mr. G With Pneumonia in Fatmawati Hospital
}

\author{
Aat Djanatunisah $^{1}$, Riri Maria $^{2}$ \\ ${ }^{1}$ Master of Nursing Student Specialization in Medical Surgery, Faculty of Nursing, University of \\ Indonesia - Indonesia \\ ${ }^{2}$ Lecturer at the Faculty of Nursing, University of Indonesia-Indonesia \\ E-mail: djanatunisah@gmail.com
}

\begin{abstract}
Pneumonia is a health problem in the world with a high mortality rate both in developing countries and in developed countries such as America, Canada and European countries. In Indonesia, the number three cause of death after cardiovascular disease and tuberculosis. Low socioeconomic factors increase mortality. This infection is generally spread from someone who is exposed in the neighborhood or has direct contact with infected people through their hands or by breathing air (droplets) due to coughing or sneezing. In the pandemic era, pneumonia is very feared because it is related to respiratory diseases which are becoming a trend and issue, so it requires special treatment in this case. This case report aims to improve the provision of nursing care for pneumonia patients to mantaining hydration status with airway clearance problems. Nursing assessment of pneumonia patients was carried out on September 13, 2020, a 52-year-old man who has a history of DM and smoking comes with complaints of coughing but no phlegm, fever since one week ago has disappeared, the patient has diarrhea since 2 days before entering the house pain and stomach pain, the patient also has nausea and vomiting and has no appetite. Nursing intervention for 3 days in accordance with the established outcome criteria. From the nursing intervension carried out, the problem of clearing the airway was resolved, marked by no coughing, normal breathing, no ronchi, moist mucosa and no cyanosis. Nursing intervention to maintaining the patient's adequate hydration status can overcome the problem of ineffective airway clearance.
\end{abstract}

Keywords: Pneumonia, Airway Clearance, Hydration Status

\section{Introduction}

Pneumonia is a health problem in the world with a high mortality rate both in developing countries and in developed countries such as America, Canada and European countries. In America there are two million cases of pneumonia per year with an average number of deaths of 45,000 people (SA. Price, 2005).

In Indonesia, the number three cause of death after cardiovascular disease and tuberculosis. Low socioeconomic factors increase mortality. Pneumonia in society is generally caused by bacteria, viruses and microplasma. Symptoms of pneumonia itself are fever, shortness of breath, rapid pulse, green or rubbery phlegm, and X-ray images show density in the lung.

This density occurs because the lungs are filled with fluid, which is the body's reaction to kill bacteria, as a result, lung function will be disrupted and the patient 
has difficulty breathing because there is no room for oxygen (Jeremy, 2007).

This infection is generally spread from someone who is exposed to their living environment or has direct contact with infected people through their hands or by breathing air (droplets) due to coughing or sneezing (WHO 2016 in Nikmah atika 2018). Older people undergo various physiological changes related to the aging process.

Various factors contribute to the increased incidence of pneumonia. In old age, there are changes in the immune system, both natural and adaptive (Mulyana, 2019). Complications in Pneumonia patients that cannot be treated properly but will result in symptoms of shock, respiratory failure, atelectation, pleural effusion and confusion. (Brunner \& suddart 2013).

To overcome or prevent these complications requires action or a medical role, pharmacology. To deal with complications from pneumonia, nurses have a role as providing nursing care where nurses are able to care for the basic human body needs through providing nursing services by using the nursing process.

The problem of ineffective airway clearance in pneumonia is due to an infectious process, an allergic response, and retained secretions.

In pneumonia, this unproductive cough occurs as a result of an infectious process that makes the respiratory mucosa dry so that it can stimulate coughing in patients, besides that it is an unproductive cough that is caused by pneumonia patients due to the body's evaporation process due to high fever, and Other symptoms include lack of appetite, which reduces fluid and nutrient intake. One of the nursing actions needed is to educate on increasing oral fluid intake so that the body's fluid balance is adequate (NANDA, 2018) and increased humidity in the mucosa in the airway. (Evans 1998; Middleton 1991).

Based on a systemic review of several RCTs examining the effect of increasing fluid intake in patients with acute respiratory infections and it was concluded that increasing the oral fluid intake in patients with respiratory tract infections can moisturize or maintain airway mucosa.

\section{Case Illustration \\ Medical history}

Mr. G, 52 years old, came to the ER on September 13, 2020 at 03.00 WIB. The patient presented with complaints of right stomach pain, nausea and vomiting, coughing without phlegm, fever since one week ago. The patient also said that he had liquid bowel movements since two days ago. Currently, the patient care room complains that they are still coughing without any phlegm and fever that comes and goes.

The patient had Diabetes millitus since 5 years ago by taking the drug Merformin $1 \times 850 \mathrm{mg}$ and Glimepiride 1x2mg. Smoking history (+), history of travel to a pandemic area (-). Family history of diabetes, heart disease, asthma, hypertension is denied.

\section{Physical and Diagnostic Examination}

General condition weak, GCS 15, E4 M6 V5, Compos mentis, T / D 110/70 mmHg, Pulse 96 x / minute, Respiratory 20 $\mathrm{x}$ / minute, Temperature 37.20C, O2 Saturation $95.7 \%$, nasal oxygen cannula installed 3 liters / minute. Symmetrical shape of the chest, no breathing muscle assistance, no nostril breathing, no cyanosis, no clubbing of the fingers, intact skin on the part of the chest, normal breathing $20 \mathrm{x} /$ minute, no tightness.

Increased tactile fremitus, and gentle, symmetrical breathing movements to the right. palpation Normal tracheal position, palpation of chest pain and crepitus absent, JVP does not increase, enlargement of lymph nodes is absent, no spinal disorders. Hyperresonant because there are infiltrates in both lungs. Left and right vesicular breath sounds, Ronchi in both lung bases, wheezing absent. Hemoglobin 13.3, Leucocytes 34.9 thousand / ul, gr / dl, Quantitative CRP 15.3 mgldl, Quantitative PCT 0.89 ng / Ml, Fibrinogen 798 mg / dl D 
Dimer $3530 \mathrm{mg} / \mathrm{dl}$, Blood Gas Analysis PH 7,437, PCO2 $36.3 \mathrm{mmHg}$, PO2 75.7 $\mathrm{mmHg}, \mathrm{HCO} 323.9 \mathrm{mmHg}$, BE $0.2 \mathrm{mmol} /$ L, O2 saturation 95.7\%. Sodium $123 \mathrm{mmol} /$ 1, Kaliunm $2.50 \mathrm{mmol} / \mathrm{l}$, Chloride $98 \mathrm{mmol}$ / 1. BMI: 24, 56 BW: $71 \mathrm{~kg}$, TB: $170 \mathrm{~cm}$, GDS $170 \mathrm{mg} / \mathrm{dl}$, Albumin $2.70 \mathrm{~g} / \mathrm{dl}$. CT scan of whole abdomen: Consolodiation with ground glass opacity image reaching peripherally in both lungs visualized, DD / typical viral pneumonia, pneumonia. Photo thoracic: Infiltrate appears in both lungs reaching the periphery side of DD / viral pneumonia, pneumonia.

\section{Pharmacotherapy}

Sucralfat $4 \times 1$ tbsp orally, NAC $3 \times 200$ $\mathrm{mg}$ orally, Oseltamifir $2 \times 75 \mathrm{mg}$ orally, Omeperazole 2x40 mg IV, Cefriaxone 2x2 g IV, Levofloxacine 1x750 mg IV, Vitamin C $3 \times 100 \mathrm{mg}$ IV, Heparin 2x5000 ui SC, IVFD Nacl $0.9 \%$ per 8 hour. Diagnose keperawatan, Bersihan jalan napas tidak efektif, Gangguan pertukaran gas, Gangguan keseimbangan cairan dan elektrolit, Resiko nutrisi kurang dari kebutuhantubuh.

\section{Nursing interventions}

Nursing intervention at Mr. G given includes adjusting a comfortable position to maximize ventilation, monitoring of respiratory status, vital signs, fluid balance, nutritional status and neurological status.

Collaborative action for providing antibiotic therapy, anticoagulant, mucolytic, antiemetic, vitamin supplements and parenteral fluids, the next collaboration is with nutritionists for patients' patients besides providing complementary therapy by providing eucalyptus aromatherapy which is efficacious to relieve breathing and as an antioxidant and anti-inflammatory in airway infection.

In nursing action to clean the airway is not effective during treatment, fluid intake is closely monitored to maintain fluid balance, after calculating the body's fluid needs using the fresh Holiday formula, it is found that the fluid needs needed by the patient are $2140 \mathrm{cc}$ per day.
The patient is currently receiving Nacl infusion of $0.9 \% 500 \mathrm{cc}$ per 8 hours, so that parenteral fluid intake is $1500 \mathrm{cc}$ per 24 hours. So the required oral fluid intake is as much as $640 \mathrm{cc}$. At the start of the intervention on September 14, 2020 at 12.00 WIB, namely educating patients to drink as much as 640 per 24 hours.

On September 15, 2020 at 12.00 WIB calculating the intake outpout, it was found that the oral fluid intake of $600 \mathrm{cc}$, the patient could not drink much because of nausea, infusion of $1500 \mathrm{cc}$, a total of 2100 cc of incoming fluid intake, for an output of $1000 \mathrm{cc}$, the patient's fluid balance was + $1100 \mathrm{cc}$.

At 4:00 p.m., the patient said he was still coughing but there was no phlegm and an itchy throat. Good skin turgor, and the lip mucosa is moisturised. On September 16 2020 at 12.00 WIB a measurement of intake output was carried out with the results of oral fluid intake of $800 \mathrm{cc}$, infusion of 1500 $\mathrm{cc}$, the total intake was $2300 \mathrm{cc}$, while the output was $1400 \mathrm{cc}$, a fluid balance $+900 \mathrm{cc}$ was obtained, at 16.30 WIB did a review of the patient said the throat was less itchy.

On September 172020 at 12.00 WIB a measurement of the intake output was carried out, it was obtained that the oral fluid intake was $800 \mathrm{cc}$, infusion fluid was $1500 \mathrm{cc}$, the total fluid intake was $2300 \mathrm{cc}$, the output was $1500 \mathrm{cc}$ so that the fluid balance was $+800 \mathrm{cc}$, at 16.10 WIB conducting a review of the patient saying that he felt comfortable in the throat and cough reduced, elastic turgor and moist lip mucosa. Was this translation helpful?

Tabel. 1 Intake Output

\begin{tabular}{|c|c|c|c|c|c|}
\hline No & Date & Intake & Output & Balance & Complaint \\
\hline 1 & $\begin{array}{l}15-09- \\
2020\end{array}$ & $\begin{array}{l}2100 \\
\mathrm{cc}\end{array}$ & $\begin{array}{l}1000 \\
\mathrm{cc}\end{array}$ & $\begin{array}{l}+1100 \\
\mathrm{cc}\end{array}$ & $\begin{array}{l}\text { still coughing but } \\
\text { no phlegm and an } \\
\text { itchy throat }\end{array}$ \\
\hline 2 & $\begin{array}{l}16-09- \\
2020\end{array}$ & $\begin{array}{l}2300 \\
\mathrm{cc}\end{array}$ & $\begin{array}{l}1400 \\
\mathrm{cc}\end{array}$ & $\begin{array}{l}+900 \\
\mathrm{cc}\end{array}$ & $\begin{array}{l}\text { throat itching } \\
\text { lessened }\end{array}$ \\
\hline 3 & $\begin{array}{l}17-09- \\
2020\end{array}$ & $\begin{array}{l}2300 \\
\mathrm{cc}\end{array}$ & $\begin{array}{l}1500 \\
\mathrm{cc}\end{array}$ & $\begin{array}{l}+900 \\
\mathrm{cc}\end{array}$ & $\begin{array}{l}\text { comfortable } \\
\text { throat and } \\
\text { reduced cough, } \\
\text { elastic turgor and } \\
\text { moist lip mucosa. }\end{array}$ \\
\hline
\end{tabular}

\section{Discussion}


Increasing adequate body fluid intake in maintaining fluid balance can maintain mucosal moisture in the airways. In addition, increased body fluid intake is indicated to replace fluid losses due to fever and evaporation in the airways accompanied by tachycardia. (Dhawan 1992; Shann 1985).

Hydration status is a description of the balance in and out of water in the body (Baron, 2015). To maintain and increase the humidity of a good airway, among others, is to maintain an adequate hydration. Nursing actions performed on $\mathrm{Mr}$. $\mathrm{G}$ for 3 days in increasing the oral fluid intake, by measuring the patient's intake output for 24 hours.

Found on the fluid balance Mr. G always shows a positive balance, this shows that the body is not dehydrated. Increased body fluid intake at Mr. G has considered the patient's kidney and heart function.

Maintaining fluid balance can maintain heavier airway damage due to infection and evaporation can be seen in the radiological image. (Dreyfuss. 1988). After 3 days, an ineffective airway clearance was evaluated for Mr. G can be resolved by maintaining fluid balance which is indicated by the patient saying the throat is no longer itchy and feels comfortable and the cough is reduced, the skin turgor is elastic, and the lip mucosa is moist. T / D 109/67 mmHg, Pulse 97x / minute, Inhalation 20x / minute, Temperature 360C.

This nursing action is of course followed by collaborative action and complementary therapy in the handling of respiratory tract infections so that their effectiveness is better.

\section{Conclusion}

In nursing actions in increasing the intake of oral fluids in maintaining the balance of the patient's body fluids is very helpful for Mr. G who has problems with ineffective airway clearance due to airway inflammation and evaporation. A good hydration status can prevent drying of the airway mucosa. This nursing intervention looks like a very ordinary action but it can be important in overcoming the problems faced by Mr. G with ineffective airway clearance problems. The role of nurses in fulfilling fluid needs has become the responsibility of meeting basic human needs.

\section{Thank-you note}

The author would like to thank the IGD nursing team and the nursing team of the 2nd Floor IGD Fatmawati Hospital for helping carry out nursing care to Mr. G. This case study has many shortcomings with all the limitations the author has. In this case study, there was no use of funds or financial assistance from anywhere.

\section{Reference}

Babar Ali., Naser Ali Al-Wabel, Saiba Shams., Aftab Ahamad., Shah Alam Khan., Firoz Anwar., et. all. (2015). Essential oils used in aromatherapy: A systemic review. Asian Pac J Trop Biomed 2015; 5(8): 601-611

Brunner \& Suddarth (2013). Buku Ajar Keperawatan Medikal Bedah Edisi 8 volume 2. Jakarta EGC

Dhawan, A., Narang, A., Singhi, S. (1992). \{published data only\}. Hyponatraemia and the inappropriate $A D H$ syndrome in pneumonia. Annals of Tropical Paediatrics 1992:12:455-62.

Dreyfuss, D., Leviel, F., Paillard, M., Rahmani, J., Coste, F. (1988). \{published data only\}. Acute infectious pneumonia is accompanied by latent vasopressindependent impairment of renal water excretion. American Review of Respiratory Disease 1988:138:5839.

Evans, P., Miser, W. (1998). Sinusitis and pharyngitis. In: Taylor $\mathrm{R}$ editor(s). Family medicine. Principles and practice. New York: SpringerVerlag, 1998:338. 
Jeremy, P.T. (2007). At Glance Sistem Respirasi, Edisi Kedua, Jakarta, Erlangga Medical Series.

Michelle PB Guppy., Sharon M Mickan., Chris Del Mar. (2009). Advising patients to increase fluid intake for treating acute respiratory infections; Systemic review. (PDF) Advising patients to increase fluid intake for treating acute respiratory infections (researchgate.net). Diakses pada tanggal 12 Desember 2020 pukul 16.00 WIB.

Middleton, D. (1991). An approach to paediatric upper respiratory infections. Australian Family Physician 1991;44:34.

Mulyana, R. (2019). Terapi Antibiotika pada Pneumonia Usia Lanjut. Jurnal Kesehatan Andalas, 2019 Vol 8. No. 1.

http://jurnal.fk.unand.ac.id/index.ph $\mathrm{p} / \mathrm{jka} / \mathrm{issue} / \mathrm{view} / 42$. Diakses tanggal 12 Desember 17.00 WIB

Price, SA., Wilson, LM. (2005). Patofisiologi : Konsep Klinis ProsesProses Penyakit. Volume 2 Ed/6. Hartanto H, Susi N, Wulansari P, Mahanani DA, editor. Jakarta: EGC; BAB 53, Penyakit Serebrovaskular; hal. 1106-1129.

World Health Organization (2016). Pneumonia.

https://www.who.int/newsroom/fact-sheets/detail/pneumonia Diakses pada tanggal 12 Desember 2020 pukul 16.30 WIB 